стимулирования на эффективный труд. Методы мотивации не могут быть одинаковыми применительно ко всем сотрудникам.

Таким образом, формируется профессиональный мотивированный коллектив сотрудников, способных решать задачи учреждения и стремится к достижению цели учреждения.

$$
* * *
$$

1. Егоршин А. П. Мотивация трудовой деятельности: учебное пособие. Н. Новгород: НИМБ, 2003. $320 \mathrm{c}$.

2. Зимняя И.А. Педагогическая психология: Учеб. пособие. Ростов-на-Дону, 1997. С. 480.

3. Основы социальной работы. Учебник / Отв. ред. П.Д. Павленок. - М.: ИНФРА-М, 1998. - 368 с.

4. Шмелев Н.Б. Формирование и развитие личности социального работника как профессионала: Учеб. пособие. - М.: Издательско-торговая корпорация «Дашков и К*», 2004, С. 92.

\title{
Галкина А.А. \\ Конструктивный подход в системе образования (понятие «конструкт», компоненты организации педагогического процесса)
}

Муниципальное бюджетное общеобразовательное учреждение средняя общеобразовательная школа №70

(Россия, Липецฺк)

doi 10.18411/spc-12-01-2018-02

idsp 000001:spc-12-01-2018-02

Многими учеными-исследователями отмечается, что традиционная система образования уже не отражает в полной мере изменения в окружающей реальности, отстраняя учащихся от нее, не способствуя духовному развитию, формируя знания и представления, не соответствующие реальному жизненному опыту. Это можно объяснить тем, что знания в традиционной системе образования воспринимаются как сакральные ценности, которые должны приниматься как само собой разумеющееся. Это не всегда отвечает индивидуальному опыту личности и очень часто приводит к тому, что после изучения и усвоения учебного материала, полученные и якобы усвоенные знания забываются, т.к. не опираются на жизненный опыт. Отмечается оторванность традиционной системы образования от самого процесса жизни. Одновременно с этим происходит постоянное развитие образовательных программ, что влечет за собой минимум внимания на становление знаний. При традиционной системе образования отмечается пассивное запоминание материала, а учащийся выступает в роли пассивного объекта в процессе обучения, получая определенные знания, применимые в стандартной ситуации, но, возможно, абсолютно ненужные в реальной действительности (Богданова, 2012). Поиск новых альтернатив-систем образования привел к возникновению такого широкого направления как педагогический конструктивизм, основная идея которого состоит в том, что знания нельзя передать в готовом виде. Познание в педагогическом конструктивизме представляет собой некий процесс адаптации к окружающему миру, выражающийся в эффективности решения жизненных задач. Во время обучения необходимо создавать педагогические условия для успешного получения знаний обучающихся. Д. Дьюи отмечал, что обучение представляет собой жизнь в ее особой форме, поэтому необходимо формировать навыки выработки конкретных решений у обучающихся. По мнению Д. Дьюи, истинное образование дает возможность получить знания в процессе «делания», актуальность знаний определяется вкладом в «становление системы внутренней личностной ориентации». Знания - это не сама цель образования, а лишь средство для решения жизненных проблем. В педагогическом конструктивизме ценность представляет сам процесс познания. Истина выступает в качестве итога проделанной работы, собственного открытия. Ценность знания заключена в его субъективности, т.к. 
знание в конструктивизме выступает не в качестве пассивных сведений о реальности, а в качестве собственного опыта (Дьюи, 2000, Богданова, 2012).

По мнению Н.П. Шаталовой, в связи с постоянно меняющимися концепциями в процессе обучения в последние годы, образовательный процесс рассматривается в качестве конструктивного поиска новых стратегий и технологий в данной сфере, а конструктивный подход представляет особый интерес. Основными причинами выступают: 1) прогрессивность конструктивного обучения, когда традиционные теории и методы отходят в сторону, и ведется поиск новых решений, основанных на изучении развивающих методик; 2) процесс самопознания проблемы (при решении различных педагогических задач на основе изучения и сопоставления с предыдущими); 3) присутствие конструктивных отношений между преподавателем и обучаемым в процессе общей деятельности. Предполагается, что конструктивное мышление и конструктивные навыки преподавателя регулируют взаимоотношения между обучающим и обучающимся; 4) структуризация учебной деятельности (подготовка к занятию со стороны преподавателя, планируемый результат и план действий для его достижения со стороны учащегося). Так как конструктивное обучение основывается на опыте прошлого, навыки структурирования зависят от умения анализировать ситуации и, пытаясь решить проблему, сопоставлять ее с ранее возникшими и схожими. Конструктивное обучение ведет к «поиску новых технологий и приемов в области обучения» (Шаталова, 2010). В конструктивное обучение включен также и творческий процесс. По мнению Н.П. Шаталовой, конструктивное обучение представляет собой более гуманный путь «К развитию и самосовершенствованию», т.к. именно конструктивный подход помогает понять смысл принимаемых решений, разграничить «информацию» от знания, признать личное мировоззрение. Н.П. Шаталова, признавая необходимость формирования профессионального конструктивного мышления, предлагает понимать под конструктивностью процесс, «содержащий способы превращения алгоритмов (конструктов) деятельности в проект организации» (Шаталова, 2010). При конструктивном обучении Н.П. Шаталова ведущим конструктом считает воспитание конструктивной личности, опираясь на личностные особенности и возможности. В качестве конструктов она также отмечает цели деятельности, которые изменяются в процессе конструирования объектов познания (Шаталова, 2016).

Под конструктом (педагогическим) Н.В. Бордовская понимает некий результат разработанной педагогической модели (технологии, системы) с eе апробацией (организацией, внедрением) и рядом признаков (параметров, критериев), оценивающих эффективность данного конструкта (Бордовская, 2001). Козырева О.А. и Громова В.В. определяют педагогический конструкт как модель оптимизации и организации педагогической деятельности, педагогические средства, повышающие качество решения задач в работе педагога. К педагогическим конструктам Козырева О.А. и Громова В. В., относят элементы и продукты современного образования, помогающие определить и решить те или иные задачи. Например, педагогическим конструктом при решении педагогической задачи может являться «построение системы принципов педагогического взаимодействия», анализирующей качество решения педагогических проблем (Громова, Козырева, 2016, с. 198). В качестве конструкта Усольцев А.П. и Антипова Е.П. рассматривают некий алгоритм подготовки преподавателя к занятию, выделяя «операциональными компонентами конструкта» такие понятия как уровень «усвоения и уровень осознанности» (Усольцев, Антипова, 2017, с. 61). Наблюдаются разные вольности в толковании терминов «педагогический конструкт» и «дидактический конструкт». Например,Кадиров А.M. в своей научноисследовательской работе данные термины рассматривает как синонимичные (дис. Кадиров, 2011). Однако здесь следует сделать некоторые уточнения и разграничения в терминологии. Исходя из того, что под педагогикой понимают особую социально и личностно детерминированную науку, «характеризующуюся педагогическим целеполаганием и педагогическим руководством», как некую деятельность «по приобщению человеческих существ к жизни общества» (Педагогика, 2004, с. 5), а под 
дидактикой - «составную часть педагогики, науку об обучении», которая исследует «законы, закономерности, принципы, цели, содержание, формы, методы, средства обучения» и объектом которой выступает обучение, представляющее собой «целенаправленный процесс взаимодействия» обучающих и обучаемых, «направленный на решение учебных задач», результатом которого являются полученные знания, умения, навыки учащихся, развитие их личностных качеств, формирование их компетентности (Краевский, Хуторской, 2007, с. 20-25), понятия «педагогический конструкт» и «дидактический конструкт» следует разграничивать. Дидактический конструкт включает компоненты организации обучения. Педагогический конструкт содержит компоненты организации воспитания, развития и обучения. То есть, педагогический конструкт по своему значению шире. Можно сказать, что дидактический конструкт является частью педагогического, как и сама дидактика является частью педагогики.

Известно, что предметом исследования педагогики является воспитание, а одна из важных функций воспитания - передача накопленного человеческого опыта новым поколениям- осуществляется через образование, ядром которого является обучение, представленное преподаванием (передачей опыта) и учением (усвоением опыта). Для передачи и усвоения знаний необходимо установить тесную и комфортную взаимосвязь между преподавателем и учащимися в совместной учебной деятельности. Для этого в настоящее время разрабатываются различные педагогические технологии и педагогическое проектирование. Педагогические технологии позволяют продумать последовательность действий участников образовательного процесса. Разработка конкретной педагогической технологии - это процесс педагогического проектирования, которое представляет собой предварительную разработку деталей учебной деятельности. Объектом педагогического проектирования может стать педагогическая система, педагогический процесс или педагогическая ситуация. Главным объектом проектирования будет выступать педагогический процесс, составной частью которого является педагогическая ситуация. Во время проектирования, после разработки целей, возможностей их достижения (1-й этап) и создания модели с ее дальнейшим практическим использованием (2-й этап), на третьем этапе создание конструкта детализации проекта, возможности использования в конкретных условиях участниками образовательного процесса (Буланова-Топоркова, 2002). В данном случае речь идет о разработке педагогического конструкта.

Исследуя проблемы образования и обучения, дидактика в свою очередь, выделяя иерархию задач, ставя на первое место приобщение к общечеловеческим ценностям в качестве генеральной задачи, на втором месте решая специфические задачи дидактики в качестве теории обучения, определяя объем и содержание, на третье место, среди специфических задач технологического обучения ставит выделение дидактического конструкта процесса обучения (Ситаров, 2004, с. 14). То есть преподавателю предлагается найти некий инструмент, алгоритм последовательности действий, с помощью которого можно было бы организовать образовательный процесс, в частности организацию и усвоение нового материала.

Следует отметить, что такие понятия как «дидактические средства», «дидактический материал» и «дидактический конструкт» не являются тождественными. В настоящее время различные технологии обучения используют широкий спектр дидактических средств, классификацию которых в свое время сделал польский ученый В. Оконь в своей работе «Введение в дидактику». Отмечая, что дидактические средства призваны служить оптимизации преподавания и учения, он выделил простые и сложные дидактические средства. К простым средствам В. Оконь отнес словесные (учебники, печатные тексты) и простые визуальные (картины, диаграммы, карты, необычные предметы. модели). Сложные средства были представлены механическими визуальными (напр., фотоаппарат, микроскоп, телескоп и т.д.), аудиальными (напр., магнитофон), аудиовизуальными (напр., телевизор), а также средствами, автоматизирующими процесс обучения (напр., лингвистические кабинеты, 
дидактические машины, компьютеры и т.д.) (Оконь, 1990, с. 294). Он также классифицировал дидактические машины по основным функциям: приобретение информации (машина-инструктор), закрепление материала (машина-репетитор), формирование практических умений (машина-тренер), проверка овладениями знаний (машина-экзаменатор) и универсальная машина, выполняющая все перечисленные ранее четыре функции (Оконь, 1990, с. 258). Признавая относительное несовершенство классификации дидактических средств, В. Оконь отмечал ее необходимость для характеристики чаще всего используемых средств обучения.

Помимо понятия «дидактические средства» существует понятие «дидактический материал». Под дидактическим (учебным) материалом понимают наглядные учебные пособия (таблицы, карточки с цифрами, рисунками и т.д., которые преподаватель показывает на занятии или раздает учащимся для самостоятельной работы. Дидактический материал прост по содержанию и оформлению, может быть изготовлен самими учащимися. К дидактическому материалу также относятся сборники задач и упражнений (Психолого-педагогический словарь, 2006, с. 184-185).

Особый интерес представляет учебник. Он является важнейшим средством организации учебного процесса, особенно при самостоятельном обучении. И.П. Подласый выделил три дидактические функции учебника: мотивационную (создание стимулов, побуждающих изучать предмет, формировать интерес к работе), информационную (расширение объема знаний), контрольно-корректирующую (тренировочную, дающую возможность проверки полученных знаний). Д. Д. Зуев в структуре учебника выделяя тексты как главный компонент, отмечает еще вспомогательные внетекстовые компоненты - вопросы, таблицы, упражнения, иллюстрации и т.д. (Ситаров, 2004, с. 197-199) Таким образом, учебник, являясь дидактическим средством обучения, полон дидактического материала.

Исходя из выше изложенного и дидактические средства, и дидактический материал являются основными компонентами организации обучения.

$$
* * *
$$

1. Богданова, В.О. Педагогический конструктивизм: образование как адаптация // Философия образования. 2012. № 5. С. 41-46.

2. Бордовская, Н.В.Диалектика педагогического исследования: Логико-методологические проблемы. СПб.: РХГИ, 2001. $512 \mathrm{c.}$

3. Буланова-Топоркова М.В. Педагогика и психология высшей школы: учебное пособие. . - Ростовна-Дону: Феникс, 2002. - 544 с.

4. Громова, В.В., Козырева, О. А. Педагогические конструкты как формы оптимизации качества педагогических решений // Инновационная наука. 2016. №6. С. 198-199

5. Дьюи Дж., Дьюи Э.Школы будущего [Электронный ресурс]: // Народное образование. - 2000. - № 8. URL: http://jorigami.ru/PP_corner/Classics/Dewey/Dewey_Schools_of_Future.htm

6. Кадиров, А. М. Коммуникативное образование в современных университетах США :Дис. канд. пед. наук : 13.00.01 / Кадиров А. М.; [Место защиты: Рос. гос. пед. ун-т им. А.И. Герцена]. - СанктПетербург, 2011. - 192 с. : ил.

7. Краевский В.В., Хуторской А.В. Основы обучения: Дидактика и методика. Учеб. пособие для студ. высш. учеб. заведений. - М.: Издательский центр «Академия», 2007. - 352 с.

8. Оконь, Винценты Введение в общую дидактику: Пер. с польск. Л. Г. Кашкуревича, Н. Г. Горина. M.: Высш. шк., 1990. - 382 с. Пер. изд.: Okon W. WprowadzeniedoDydaktykiOgolnej. PanstwoweWydawnictwoNaukowe, 1987.

9. Педагогика: Учебное пособие. / Под ред. П. И. Пидкасистого. 2004. - 334 с. [Электронный ресурс]. URL: http://sdo.mgaps.ru/books/K4/M11/p2/4.pdf

10. Психолого-педагогический словарь. / Сост. Рапацевич Е.С. - Минск, 2006, с. 184-185.

11. Ситаров В.А. Дидактика: Учеб. пособие для студ. высш. пед. учеб. заведений / Под ред. В.А. Сластенина. - 2-е изд., стереотип. - М.: Издательский центр «Академия», 2004. — 368 c.

12. Усольцев А. П., Антипова Е. П. О конструктах уроков по ФГОС // Образование и наука. 2017. Т. 19, № 5. C. 55-71. DOI: 10.17853/1994-5639-2017-5-55-71.

13. Шаталова. Н.П. Конструктивизм в образовании [Электронный ресурс]: электрон. данные. - Москва: Научная цифровая библиотека PORTALUS.RU, 14 апреля 2010. URL: http://portalus.ru/modules/pedagogics/rus_readme.php?archive\&id=1271195149\&start_from\&subaction=s howfull

14. Шаталова Н.П. Конструктивный подход в педагогике как ведущий принцип науки // Педагогический журнал. 2016. № 1. С. 62-70. 